BMJ Open Sport \& Exercise Medicine

\title{
Taking the lead towards healthy performance: the requirement of leadership to elevate the health and performance teams in elite sports
}

\author{
Evert Verhagen (D), ${ }^{1}$ Jay Mellette,${ }^{2}$ Jeff Konin, ${ }^{3}$ Reggie Scott, ${ }^{4}$ João Brito (D), ${ }^{5}$ \\ Alan McCall (iD 6
}

To cite: Verhagen E, Mellette J, Konin J, et al. Taking the lead towards healthy performance: the requirement of leadership to elevate the health and performance teams in elite sports. BMJ Open Sport \& Exercise Medicine 2020;0: e000834. doi:10.1136/ bmjsem-2020-000834

Received 16 May 2020 Revised 6 August 2020 Accepted 13 September 2020

Check for updates

(c) Author(s) (or their employer(s)) 2020. Re-use permitted under CC BY-NC. No commercial re-use. See rights and permissions. Published by BMJ.

${ }^{1}$ Amsterdam Collaboration on Health and Safety in Sports, Department of Public and Occupational Health, Amsterdam Movement Sciences, Amsterdam UMC, University Medical Centers - Vrije Universiteit Amsterdam, Amsterdam, Netherlands ${ }^{2}$ Vegas Golden Knights, National Hockey League, Las Vegas, Nevada, USA

${ }^{3}$ Department of Athletic Training, Florida International University, Miami, Florida, USA

${ }^{4}$ Los Angeles Rams, National Football League, New York, New York, USA

${ }^{5}$ Portugal Football School, Portuguese Football Federation, Oeiras, Portugal

${ }^{6}$ Arsenal Performance and Research Team, Arsenal Football Club, London, UK

\section{Correspondence to}

Evert Verhagen;

e.verhagen@amsterdamumc.nl

\section{ABSTRACT}

Where not too long ago we serviced athletes; nowadays, we have the responsibility to lead a multidisciplinary team that is mandated to protect the athletes' health, ensure competition availability and ability to compete at peak performance. In essence, our roles have shifted from being a service provider to a health and performance manager who steers a multidisciplinary team of specialists. In this viewpoint, we question whether we really have the skills to lead a 'team' like this effectively. We provide a potential definition of leadership and discuss the importance of leadership for health and performance teams with recent literature. Finally, we share our baseline 'leadership' pearls that allow you to elevate collaboration through leadership.

\section{DO WE REALLY POSSESS SKILLS TO EFFECTIVELY LEAD A MULTIDISCIPLINARY TEAM?}

Sports has evolved rapidly over the past decades. With an increased economic value and drive to be competitive, a surge of professionalisation has taken place internationally across various levels of play and over a multitude of sports. In the contemporary sports arena, athletes have become highvalue assets in a business that is driven by athletic performance and, ultimately, results. This development also affects the role as clinical and sports science professionals.

Where not too long ago we serviced athletes; nowadays we are tasked with leading a multidisciplinary team that is mandated to protect the athletes' health and ensure competition availability and ability to compete at peak performance. ${ }^{1}$ Our roles have evolved, more so by default than intention, from being sports clinicians and sports science professionals to, for instance, directors/heads of health and performance. In essence, our responsibilities have shifted from being a service provider to a health and performance manager who steers a multidisciplinary team of specialists. The question is whether we really have the skills to lead a 'team' like this effectively?

\section{THERE SHOULD BE A LEADER IN ALL OF US}

It is our responsibility to protect the athlete from harm, make sure the athlete is available and prepare the athlete to perform at peak performance. In case of injury, we are entrusted with the task to get the athlete back to perform safely but quickly. Likely, we all faced the struggles this brings due to differing responsibilities and decisions within an athletic context. We are constantly balancing the well-being of the athlete against the 'necessity' to perform. This makes it not always possible to sideline an athlete, even though that would be our preferred option. After all, missed participation may equate to reduced performance and does lead to greater organisational expenses.

Here within lies a contemporary aspect of sports performance: leadership. While the term leadership is applicable across a wide range of contexts, various definitions exist. A classic definition is from Barrow who defined leadership as 'the behavioural process of influencing individuals and groups toward set goals', ${ }^{2}$ or in the words of Dwight D. Eisenhower 'Leadership is the art of getting someone else to do something you want done because he wants to do it. ${ }^{3}$ This relates to athlete health and performance as we are tasked to facilitate and guide our multidisciplinary department and defend our teams' mandate, views and decisions to other stronger voiced roles who may have conflictingperformance driven-directives (eg, the coach). It is up to us to make sure variant and divergent directives are aligned with our mission of athlete health and performance.

\section{LEADERSHIP AND MANAGEMENT}

Leadership is often mentioned in a single breath with management. Both terms actually refer to different concepts which are not mutually exclusive. Management entails the administration and control of daily and 
planned processes. To streamline processes management frameworks are used to support the decision-making and the analyses of processes. ${ }^{4}$ Such frameworks are described by many in the literature, and each provides unique value fitting to a specific context. ${ }^{45}$ In essence, these frameworks are very similar. They describe the processes, tasks and tools that are required for the planning and governing of projects from start to finish. Although knowledge and expertise with management processes and frameworks are certainly a good asset to bring to the table, the application of these frameworks will not work without effective leadership.

\section{IMPORTANCE OF EFFECTIVE LEADERSHIP FOR ATHLETIC PERFORMANCE}

Over the years, most research on leadership in sports has focused on the coach and manager. This research studied their roles and impact on performance. ${ }^{6}$ In contrast, little has been done regarding effective leadership in health and performance departments. Some preliminary evidence exists though where it was shown that coaching style and team communication are linked to team injury risk and player availability. ${ }^{7}$ ${ }^{8}$ Other insights stem from recent qualitative research that described that the entire staff needs to be engaged in athlete health protection and effectively communicate with athletes about symptoms and injuries. ${ }^{9}$ Likewise, it was shown in an artistic environment that the potential for targeting injury risk factors lies also outside the realm of medical care and sits in other departments within an organisation; for example, coaching, casting and artistic teams. ${ }^{10}$ Therefore, it would only flow logically to assume that those who know how to manage and communicate effectively, and thus unlock the potential of their multidisciplinary teams, will do a better job in having the athletes ready to perform safely at their peak. So yes, effective leadership is important for health and performance.

\section{BRING OUT YOUR INNER LEADER}

Some might be natural-born leaders, others have learnt by trade, some by a combination of the two, but likely most of us struggle and possibly feel out of our depth. Leaders can be developed by following some baseline 'leadership' pearls that allow you to elevate collaboration through leadership.

1. It is not about you! The golden pearl is to lose your ego. Effective leaders make success a team effort and take personal responsibility in case of failure.

2. You can't do it alone! Communication is certainly not easy, but you must nurture an ecosystem of trust and cooperation through effective communication. As we rely on multiple disciplines, you must engage other stakeholders within and outside your department to join in your vision and goals.

3. Foster connection and value throughout your team! Build a team around a vision and manage the delivery of this vision through active engagement, monitoring and coaching of your staff throughout the process.

\section{BRINGING LEADERSHIP TO OUR MISSION}

This viewpoint may have made a compelling case towards leadership being a required skill in our roles as health and performance managers. There exists a vast amount of academic and popular literature on effective leadership. But how should we approach this as a field in our practice? How can we use leadership learning to guide and develop future athletic health and performance leaders? Here lies a great opportunity for research to describe the key markers for leadership success within our athletic realm. We can certainly draw upon our own lessons learnt to support future leaders in our field. After all, we have enjoyed successes to be shared and made mistakes they should not.

\section{Twitter Evert Verhagen @evertverhagen.}

Contributors EV developed the idea of this viewpoint. EV and AM wrote the first drafts. Other authors contributed equally to content and finetuning of the final text.

Funding The authors have not declared a specific grant for this research from any funding agency in the public, commercial or not-for-profit sectors.

Competing interests None declared.

Provenance and peer review Not commissioned; externally peer reviewed.

Open access This is an open access article distributed in accordance with the Creative Commons Attribution Non Commercial (CC BY-NC 4.0) license, which permits others to distribute, remix, adapt, build upon this work non-commercially, and license their derivative works on different terms, provided the original work is properly cited, appropriate credit is given, any changes made indicated, and the use is non-commercial. See: http://creativecommons.org/licenses/by-nc/4.0/.

\section{ORCID iDs}

Evert Verhagen http://orcid.org/0000-0001-9227-8234

João Brito http://orcid.org/0000-0003-1301-1078

Alan McCall http://orcid.org/0000-0003-3780-8153

\section{REFERENCES}

1 Reid C, Stewart E, Thorne G. Multidisciplinary sport science teams in elite sport: comprehensive servicing or conflict and confusion? Sport Psychol 2004;18:204-17.

2 Barrow JC. The variables of leadership: a review and conceptual framework. Acad Manag Rev 1977;2:231-51.

3 Baier B. Seven business leadership lessons from dwight eisenhower. Forbes. 2017. Available https://www.forbes.com/sites/forbesleader shipforum/2017/01/31/seven-business-leadership-lessons-fromdwight-eisenhower/\#64ffab243b18

4 Budler M, Trkman P. The nature of management frameworks. J Manag Organ 2019;1-18.

5 Sturdy A. The adoption of management ideas and practices. Manag Learn 2016;35:155-79.

6 Cotterill ST, Fransen K. Athlete leadership in sport teams: current understanding and future directions. Int Rev Sport Exerc Psychol 2016;9:116-33.

7 Ekstrand J, Lundqvist D, Davison M, et al. Communication quality between the medical team and the head coach/manager is associated with injury burden and player availability in elite football clubs. $\mathrm{Br}$ J Sports Med 2019;53:304-8.

8 Ekstrand J, Lundqvist D, Lagerback L, et al. Is there a correlation between coaches' leadership styles and injuries in elite football teams? A study of 36 elite teams in 17 countries. Br J Sports Med 2018;52:527-31.

9 Bolling C, Delfino Barboza S, van Mechelen W, et al. Letting the cat out of the bag: athletes, coaches and physiotherapists share their perspectives on injury prevention in elite sports. Br J Sports Med 2019.

10 Bolling C, Mellette J, Pasman HR, et al. From the safety net to the injury prevention web: applying systems thinking to unravel injury prevention challenges and opportunities in Cirque du Soleil. BMJ Open Sport Exerc Med 2019;5:e000492. 